\title{
Synchronous Pumice Mantle Found on Santorini Volcano
}

\author{
Walter L. Friedrich ${ }^{*}$, J. Richard Wilson ${ }^{1}$, Annette Højen Sørensen ${ }^{1}$, Samson Katsipis ${ }^{2}$ \\ ${ }^{1}$ Department of Geoscience, Aarhus University, Aarhus, Denmark \\ ${ }^{2}$ Museum of Minerals and Fossils, Perissa, Greece \\ Email: *walter@geo.au.dk
}

How to cite this paper: Friedrich, W.L. Wilson, J.R., Sørensen, A.H. and Katsipis, S. (2021) Synchronous Pumice Mantle Found on Santorini Volcano. International Journal of Geosciences, 12, 329-346. https://doi.org/10.4236/ijg.2021.124018

Received: February 26, 2021

Accepted: April 12, 2021

Published: April 15, 2021

Copyright (c) 2021 by author(s) and Scientific Research Publishing Inc. This work is licensed under the Creative Commons Attribution International License (CC BY 4.0).

http://creativecommons.org/licenses/by/4.0/

(c) (i) Open Access

\begin{abstract}
It is generally accepted that the vent of the 3.6 ka Minoan eruption was situated in the water-filled Santorini caldera prior to the Minoan eruption. One should therefore expect to find huge quantities of pumice and ash on the inner side of the caldera walls, but there is only a relatively small amount preserved. An unexpected discovery of remnants of a synchronous pumice mantle of the Minoan eruption appears to solve this enigma. A lengthy period of erosion and the intensive quarrying of pumice for the construction of the Suez Canal (1859 to 1869) led to the removal of an enormous amount of material and information for generations of geologists. The synchronous pumice mantle covered the whole caldera wall from rim to sea level. Archaeological finds under the pumice mantle show that the caldera wall was accessible and inhabited in the Bronze Age. Furthermore, this discovery documents that only one Minoan eruption took place and that the so-called "Lower pumice" does not exist on Santorini.
\end{abstract}

\section{Keywords}

Minoan Eruption, Tephrochronology, Visual Geology, Geoarchaeology

\section{Introduction}

The 3.6 ka Minoan eruption was one of the strongest experienced by humankind. On Santorini it buried a flourishing culture under a thick mantle of pumice and ash, thus creating a "prehistoric Pompeii" as it was called by Fouqué [1]. Three main phases of the eruption can be recognised in the deposits as described by Friedrich [2] (Figure 1). Prehistoric ruins on the island of Therasia and a prehistoric house on Thera were excavated by French scholars. After a period of about 120 years with no activity, excavations were started at Akrotiri in 1967 by 


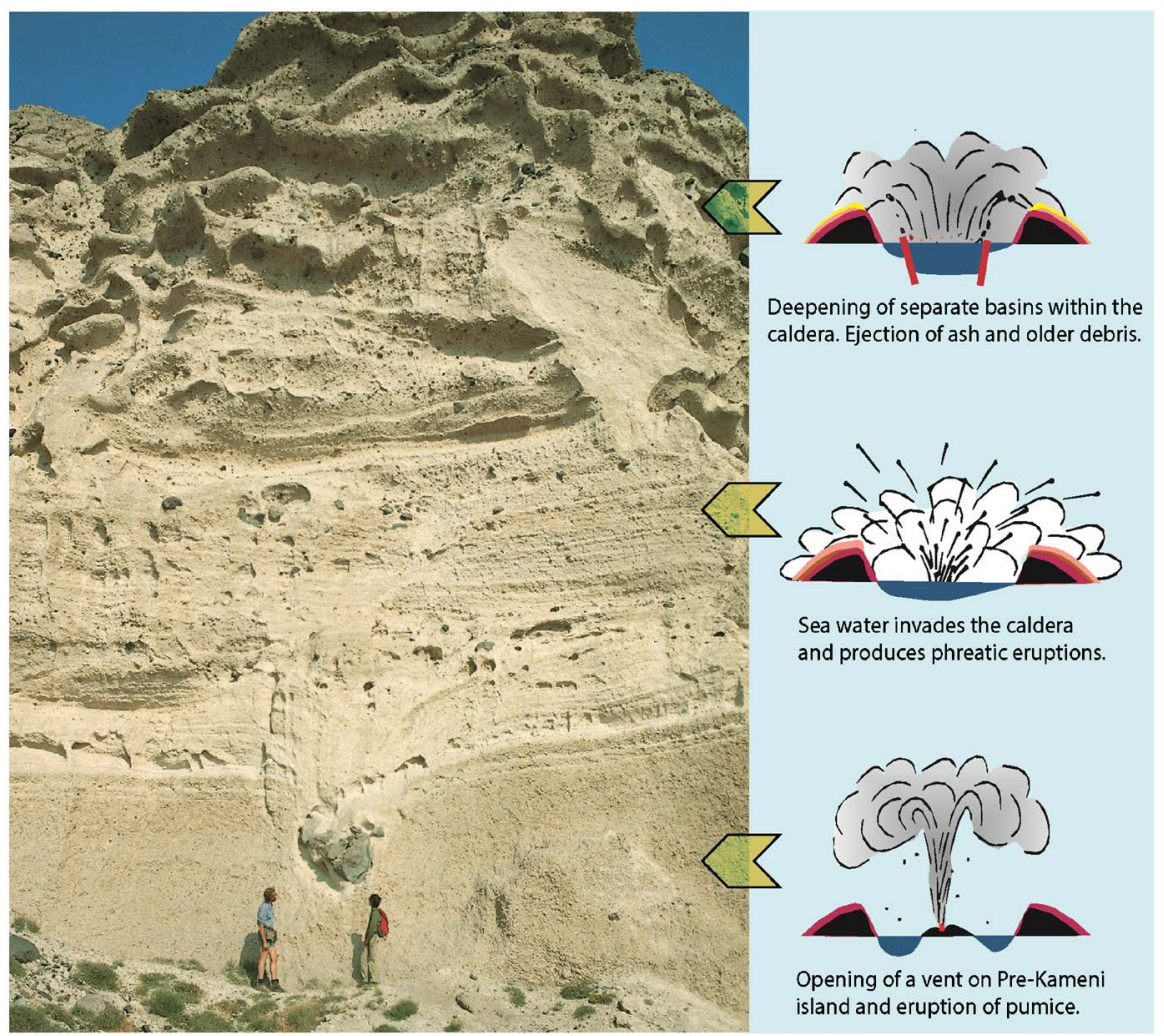

Figure 1. The photo shows the three main phases of the Minoan eruption in Fira quarry (ca. $200 \mathrm{~m}$ asl). The eruption column of the first phase (yellow arrow) reached a height of several kilometres and gave rise to air fall deposits of pumice. The entry of sea water into the magma chamber triggered ring-shaped explosions that produced base surge deposits during the second phase (green arrow). The crater widened in the third eruption phase and created pyroclastic flow (red arrow). Material on the walls of the chamber was also ejected and created bomb sacs (above the persons) in the unconsolidated deposits (Photo Friedrich).

Marinatos [3]. Here a Bronze Age town with houses with up to three stories has been excavated [4]. The houses were decorated with colourful wall paintings [5] and contained decorated pottery and other artwork. A detailed description of the Minoan eruption and its consequences for Santorini and the surrounding area is given elsewhere [6].

Here we focus on the first eruption phase, the Plinian air fall pumice that produced a huge fan that covered the Eastern Mediterranean area, creating a valuable marker horizon for both geological and archaeological correlations. The synchronous ash and pumice mantle provides a valuable tool for the chronology since all objects that are in direct and undisturbed contact with this volcanic tephra fan have the same maximum age. This pumice mantle covered the entire volcanic edifice on Santorini. One should therefore expect to find a huge amount of pumice and ash on the inner side of the Santorini caldera wall. The absence of this material remained an enigma until recent discoveries.

A new series of eruptions on Nea Kameni (1866-1870) attracted numerous scientists to Santorini to study the spectacular events in the caldera and the 
newly found prehistoric ruins that had been discovered under the pumice on Therasia. At that time Minoan pumice was being quarried on Thera and Therasia and shipped to Egypt for construction of the Suez Canal (1859 to 1869).

When the French geologist Fouque visited Santorini for the first time in 1866, he met a volcanic island that had experienced recent major changes. Pumice that had been deposited by the Minoan eruption on the inner side of the Santorini caldera was the first to be removed by this quarrying. This pumice removal led to the loss of an enormous amount of geological and archaeological information - a loss that led to wrong conclusions being made. In the 1870s Fouqué [7] considered that the volcano had produced two distinct pumice units; the Upper Pumice Series (ponce superieur) representing Minoan products) on the top of the island and the Lower Pumice Series (ponce inferieur) that represented older eruption products that were sandwiched between older and younger volcanic layers (Figure 2). Fouqué [7] [8] considered that a volcano with a height of about $450 \mathrm{~m}$ had existed in the central part of Santorini prior to the Minoan eruption.

\section{Abandoning the Two Eruptions Concept}

Fouqué's two eruptions concept was supported by a detailed illustration of the caldera walls by Neumann van Padang [9]. Since that time, the two eruptions concept was implemented in geological maps by Pichler and Kussmaul [10] and Druitt et al. [11]. Generations of geologists [12]-[18], including the senior author

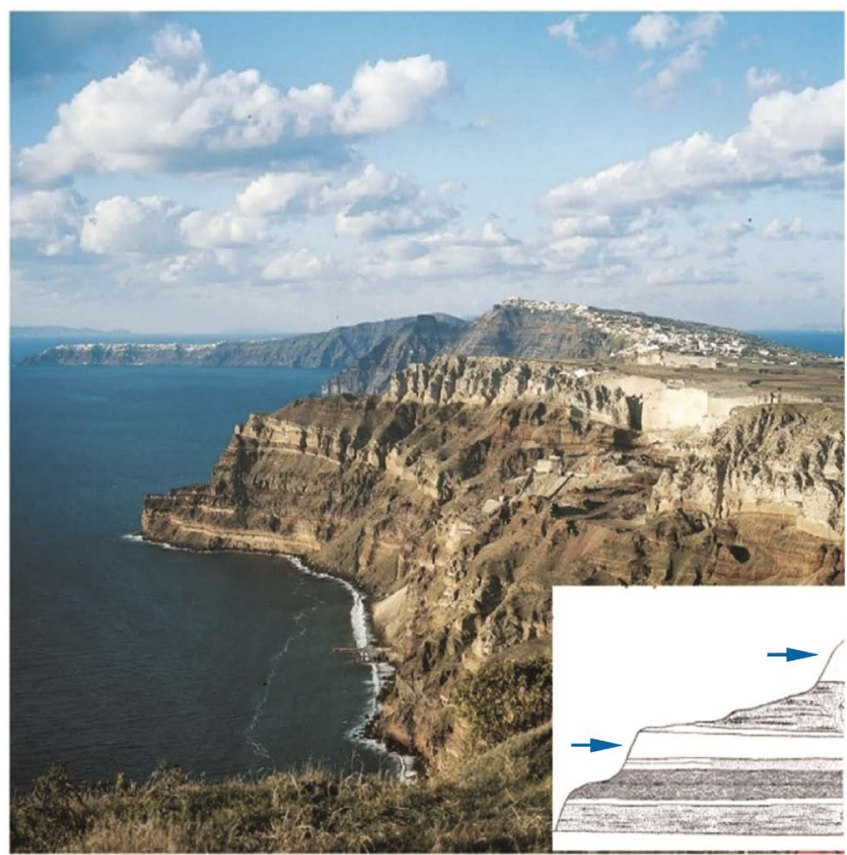

Figure 2. Santorini caldera with Cape Alonaki in the left centre photographed in 1980. The still active Karageorghis quarry is visible in the right centre. Pumice is clearly present at two levels. Here Ferdinand Fouque showed in 1879 the two pumice units (inserted drawing with arrows pointing to the lower and upper pumice series) thus giving the impression of two different eruptions. We now claim that both represent Minoan eruption products that were deposited on two terraces on the caldera wall (Photo Friedrich). 
(WLF), considered that the two apparent layers represented two different volcanic eruptions. This two eruptions concept spread to other areas in the Mediterranean where it was used in the interpretation of volcanic deposits found in several deep-sea drillings. However, this concept was abandoned when chemical analyses showed that the Lower Pumice Series encountered in the deep wells of the Mediterranean was not from Santorini [19] but had an Italian source. This was the beginning of a major change in the interpretation of the stratigraphy of the Aegean area and Santorini [20]. Today we claim that the so-called Lower Pumice Series does not exist (Figure 3 ). It is in fact part of a synchronous pumice
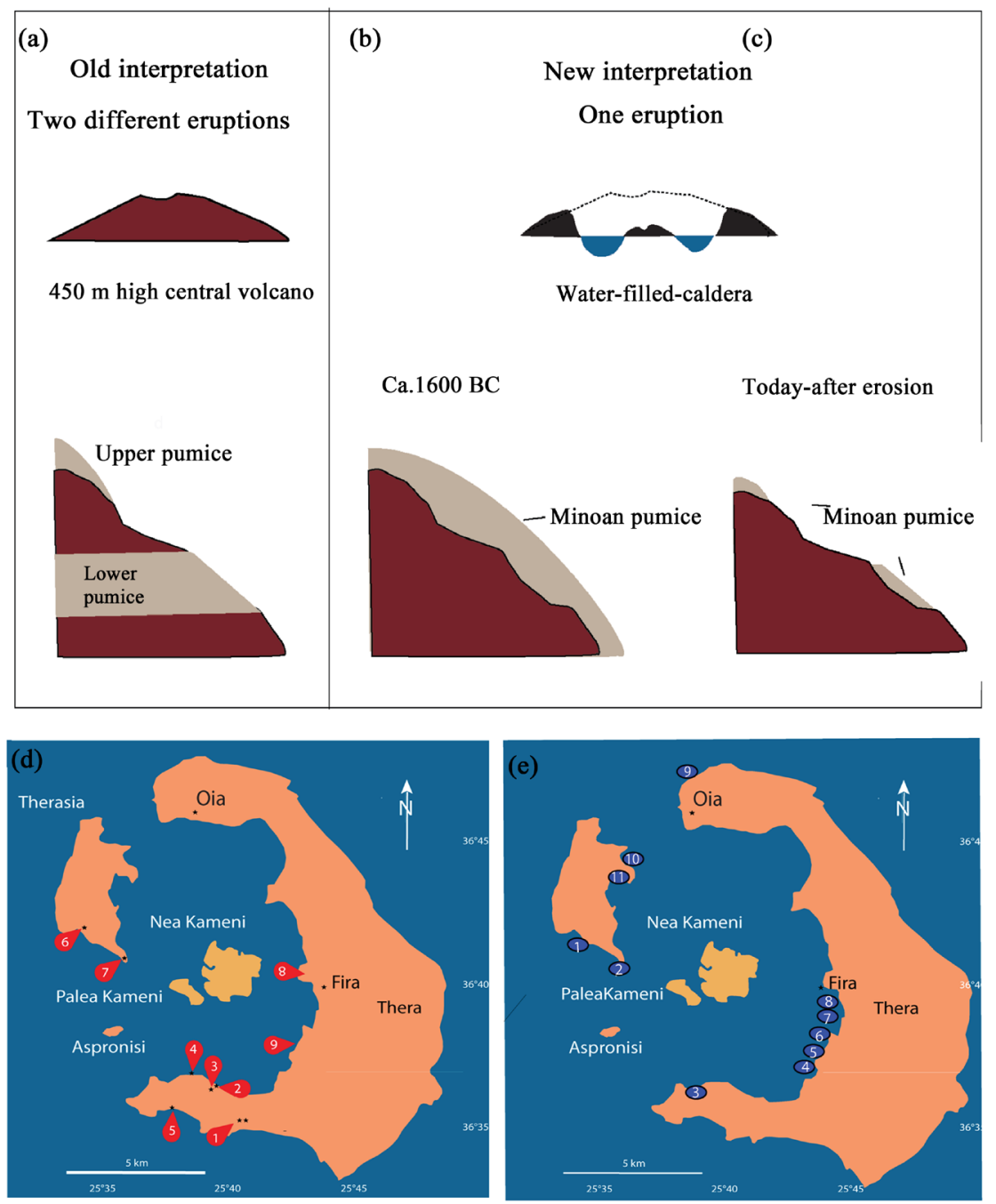

Figure 3. Schematic profiles through the caldera wall of Santorini. (a) Old concept with two pumice series with different ages. (b) The synchronous Minoan pumice mantled the entire caldera. (c) After erosion and extensive quarrying pumice only remains on terraces on the caldera wall (Wilson/Friedrich). (d) Locations of places named in the text: (1) Akrotiri excavation; (2) Balos excavation; (3) Raos excavation; (4) Kokkinopetra volcano; (5) Mavro volcano/Mesa Pigadia; (6) Alafousos quarry; (7) Kimisi; (8) Skaros castle; (9) Plaka. (e) Sites where pumice was loaded on to ships: (1) Alafousos; (2) Kimisi; (3) Balos; (4) Mavromatis; (5) Plaka; (6) Karageorghis; (7) Fira; (8) Katofira; (9) Amudhi; (10) Therasia; (11) Manolas. 
mantle of the Minoan eruption remaining on terraces on the inner side of the caldera wall, as will be shown below. Geologists, metaphorically speaking, gradually "opened" the caldera more and more. The investigations of the abovementioned groups led to general acceptance that there existed a flooded caldera prior to the Minoan eruption. This new development had some influence on interpretations by archaeologists and of the landscapes depicted on the wall paintings found in the Akrotiri excavation [21] [22] [23]. This development made it possible to imagine that the naval procession depicted in the Ship Fresco could have taken place in the flooded Santorini caldera [23].

Furthermore, lithic material in the eruption products of the Minoan eruption indicates that a so-called pre-Kameni island had existed in the water-filled Bronze Age caldera roughly where the present-day Kameni islands are situated. A breakthrough came in 1990 when the investigation of 1450 stromatolites (algae-bacterial build-ups), some of them radiocarbon dated, revealed that a flooded caldera had existed prior to the Minoan eruption [24]. This study of stromatolites that had been ejected during the Minoan eruption led to general acceptance of the idea that the caldera already existed prior to the eruption. Furthermore, numerous marine fossils found embedded in the stromatolites compellingly prove that the caldera was open and connected to the open sea, since the marine fossils needed normal temperatures and salinity to propagate [25].

Abandoning the idea of the existence of a high central volcano before the $\mathrm{Mi}$ noan eruption and acceptance of the presence of an open, water-filled caldera, means that it should be possible to find large amounts of volcanic ash and pumice from the Minoan eruption on the inner sides of the Santorini caldera walls. Much of this material has, however, been removed by erosion and quarrying. Moreover, the Akrotiri Peninsula consists of a volcano-tectonic block that is confined on its margins by five volcanoes. Marine fossils found at Mount Archangelos indicate that this block has been uplifted by about $900 \mathrm{~m}$. This developed zones of weakness along its margins, where magma rose and created the volcanoes. The line between the volcanoes Kokkino-Petra and Balos on the northern side of this block is the location of the current southern opening of the caldera. This opening probably already existed in the Bronze Age, since the tectonic movements here are much older than the Bonze Age. It therefore seems unlikely that there was a pre-Minoan eruption caldera without a connection to the open sea, as discussed by Karátson et al. [26].

\section{Pumice Quarrying on Santorini and Its Consequences}

Construction of the Suez Canal (1859 to 1869) led to enormous improvements in world trade since the sea-route from Europe to SE Asia became much shorter. There were also some unexpected consequences. On the Greek island group of Santorini, prehistoric ruins were discovered when pumice of the Minoan eruption (also called the Late Bronze Age eruption) was quarried on Therasia (Figure 
3(d)) and shipped to Egypt. Several prehistoric ruins were found under the pumice. On Thera-the main island-ruins were discovered at Akrotiri and above Balos harbour. The latter locality was excavated by the French scholars Gorceix and Mamet [27] where they found a prehistoric (later classified as Cycladic) house (Figure 3(d) and Figure 3(c)) under a $22 \mathrm{~m}$ thick layer of pumice. Fouqué [7] presents a detailed description of these finds in his book. The use of pumice as building material in the 1850s changed the look of the inner side of the Santorini caldera. Pumice that had been deposited on terraces was the first to be removed. Workers could easily move the material down to ships waiting below (Figure 3(e)). A lengthy period of erosion and, not least, quarrying of the pumice, has removed traces of it from many places on the steep caldera walls. 150 years of pumice quarrying on Thera and Therasia has left many scars in the landscape. However, most of them are only visible for specialists, because where pumice has been removed other volcanic material is now visible. Today the caldera wall on Thera shows many signs of the quarrying and export of pumice. There are the remains of several sites where ships were loaded with pumice on the caldera wall (Figure 3(e)). There is a significant concentration of such stations on the caldera wall between Skaros castle and Balos harbour, where the pumice deposits reached a thickness of about $60 \mathrm{~m}$.

\section{Terraces on Thera}

Natural terraces are formed by wind or water erosion when layers with different hardness are in contact with each other. Such terraces played a significant role for prehistoric people since they could be used for shelters and as roads for both people and animals. Natural terraces have been used by the inhabitants since formation of the Santorini caldera that occurred during or after the Cape Riva eruption (21 ka), as shown by the archaeological finds at Balos harbour (Cycladic house; Figure 4(b), Figure 4(c)) and Karageorghis quarry (Cycladic pottery).

As in other volcanic areas the thick pumice cover on Santorini was used for storage, houses, tunnels etc. An example of undiscovered tunnels appeared when a heavily laden water-transporter crashed on the road close to the centre of Fira on Santorini in 2015. This resulted in the roof of a medieval (or older) escape-tunnel breaking under the weight of the truck and opened a window into Santorini's medieval history. In medieval times [28] a large bell at Skaros castle was rung when pirates were seen in the caldera, and the inhabitants could hide or escape through tunnels that were excavated in the Minoan pumice. This accident also solved a geological enigma. It provided important evidence in the long-standing discussion concerning the two similar-looking pumice series on the caldera wall [29]. Up to $2 \mathrm{~km}$ long tunnels (Table 1, four last measurements) are only found in the "Upper Pumice Series" (for instance between the castle of Pirgos and Charalombos church in the village Exo Gonia). There are no tunnels in the "Lower Pumice Series", and caves are only a few meters deep, because they were dug into Minoan pumice mantle that remained on narrow terraces. 

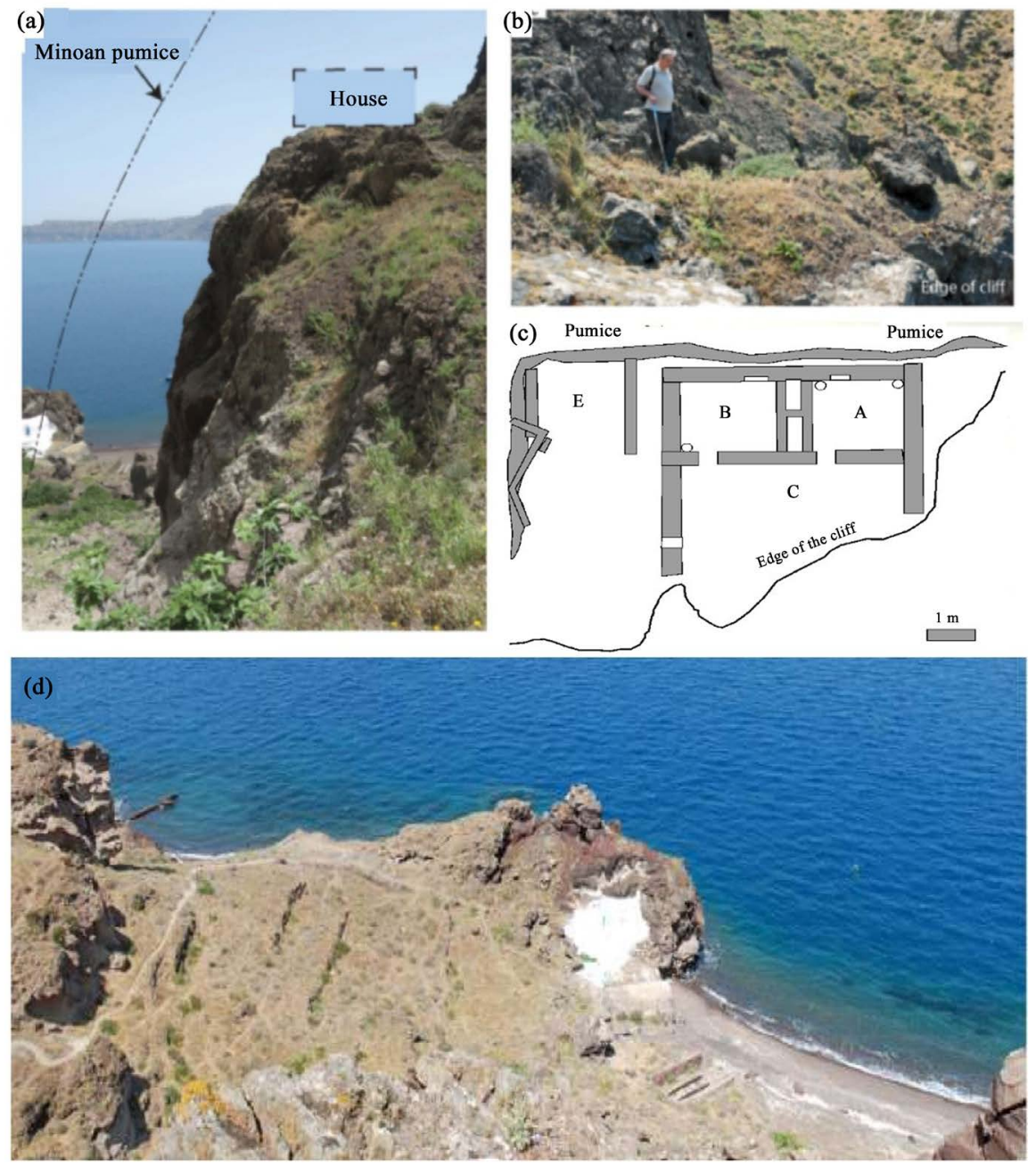

Figure 4. (a) shows the Balos locality on top of a $16 \mathrm{~m}$ thick lava knoll on a terrace. (b) The senior author is standing on the rediscovered platform where the house stood (Photo L. Huber). (c) Plan of the prehistoric house (from Fouque 1879). The small platform where the Cycladic house was excavated in 1871 by Mamet and Gorceix is still visible. It was covered by $22 \mathrm{~m}$ of pumice. (d) View from the platform showing Balos natural double harbour (Photos: Friedrich, Katsipis).

Table 1. GPS data of localities on Santorini.

\begin{tabular}{ccccc}
\hline & Latitude & Longitude & Height m.a.s.l. & Locality \\
\hline 1 & 36.3509 & 25.4028 & 3.2 & Akrotiri excavation (entrance) \\
2 & 36.4206 & 25.3327 & 77 & Alafousos quarry Therasia \\
4 & 36.226 & 25.4753 & 2.7 & Plaka, warm spring \\
5 & 36.227 & 25.475 & 62 & Plaka, talc mine \\
7 & 36.4132 & 25.4322 & 175.5 & Phtellos excavation (Doumas) \\
8 & 36.4095 & 25.4324 & 168.7 & Phtellos excavation (Marthari) \\
9 & 36.4001 & 25.4352 & 144.1 & Karageorghis quarry (Pottery) \\
10 & 36.3927 & 25.4383 & 216.7 & Two olive trees \\
12 & 36.3691 & 25.209 & 132.3 & Megalohori (unexcavated site) \\
\hline
\end{tabular}




\begin{tabular}{lrlcc}
\multicolumn{2}{l}{ Continued } \\
\hline \multicolumn{1}{l}{$\begin{array}{l}l \\
17\end{array}$} & 36.3630 & 25.3952 & 22.9 & Balos left harbour basin (filled) \\
18 & 36.3614 & 25.3903 & 164.5 & Raos excavation \\
19 & 36.3624 & 25.3946 & 62.9 & Balos excavation \\
20 & 36.2126 & 25.2289 & 168.9 & Archangelos \\
\multicolumn{2}{l}{ Tunnels on Thera } & & & Tunnel 1. Start at Casteli of Pirgos \\
21 & 36.3833 & 25.4507 & $391 \pm 7$ & Tunnel 1. End at Sxo Gonia \\
22 & 36.3843 & 25.4524 & $360 \pm 4$ & Tunnel 2. Start at Fira Pelican hotel \\
23 & 36.4183 & 25.4327 & $249 \pm 7$ & Tunnel 2. End at Fira Bellonion Center \\
24 & 36.3843 & 25.4337 & $235 \pm 7$ &
\end{tabular}

The quarrying of pumice on Santorini had some negative consequences, such as pumice dust storms that made working in the quarries temporarily impossible. For geologists, the removal of pumice provided fresh profiles with visible geology, giving insight into the mechanism of the Minoan eruption. It was straight forward to follow the deposits of the different eruption phases from outcrop to outcrop.

\subsection{A Cycladic House on a Terrace at Balos}

Balos harbour is situated north east of the village Akrotiri. Two excavation sites (Balos and Raos) above the harbour imply that it has been in use at least since the Bronze Age. While Balos was excavated by French scholars in 1871, Raos was not excavated until recently (2009 to 2012) by Marthari [30]. This harbour provides access to the water-filled caldera, which was connected to the open sea in the Bronze Age through an opening between the Akrotiri Peninsula and Aspronisi. Balos harbour (Figure 4 and Figure 5) was one of the places on Thera where the pumice quarrying started in the 1850s [31]. Figure 5(c) shows how pumice mining at that time began on the inner side of the caldera wall, where pumice could easily be moved down to the waiting ships. A prehistoric house was discovered on such a terrace at Balos which French scholars excavated in 1871. The right side of the same photograph shows the nearly intact preservation of the pumice mantle of the Minoan eruption. This wall may have been spared from quarrying because it would have damaged houses on the beach belonging to fishermen. This wall shows remnants of pumice at three levels that remain after 3600 years of erosion. Figure 5(a) shows the same wall highlighted in the evening sun. It reveals the characteristic details of the weathering pattern of the base surge layers. Deposits of the Minoan eruption are clearly visible, indicating that the synchronous pumice mantle originally covered the entire inner side of the caldera wall.

Minoan pumice is still visible at several levels on the caldera wall at Balos harbour (Figures 5(a)-(c)). Neuman van Padang [9] was not able to locate the prehistoric house above Balos harbour. When he mapped the "Lower Pumice 

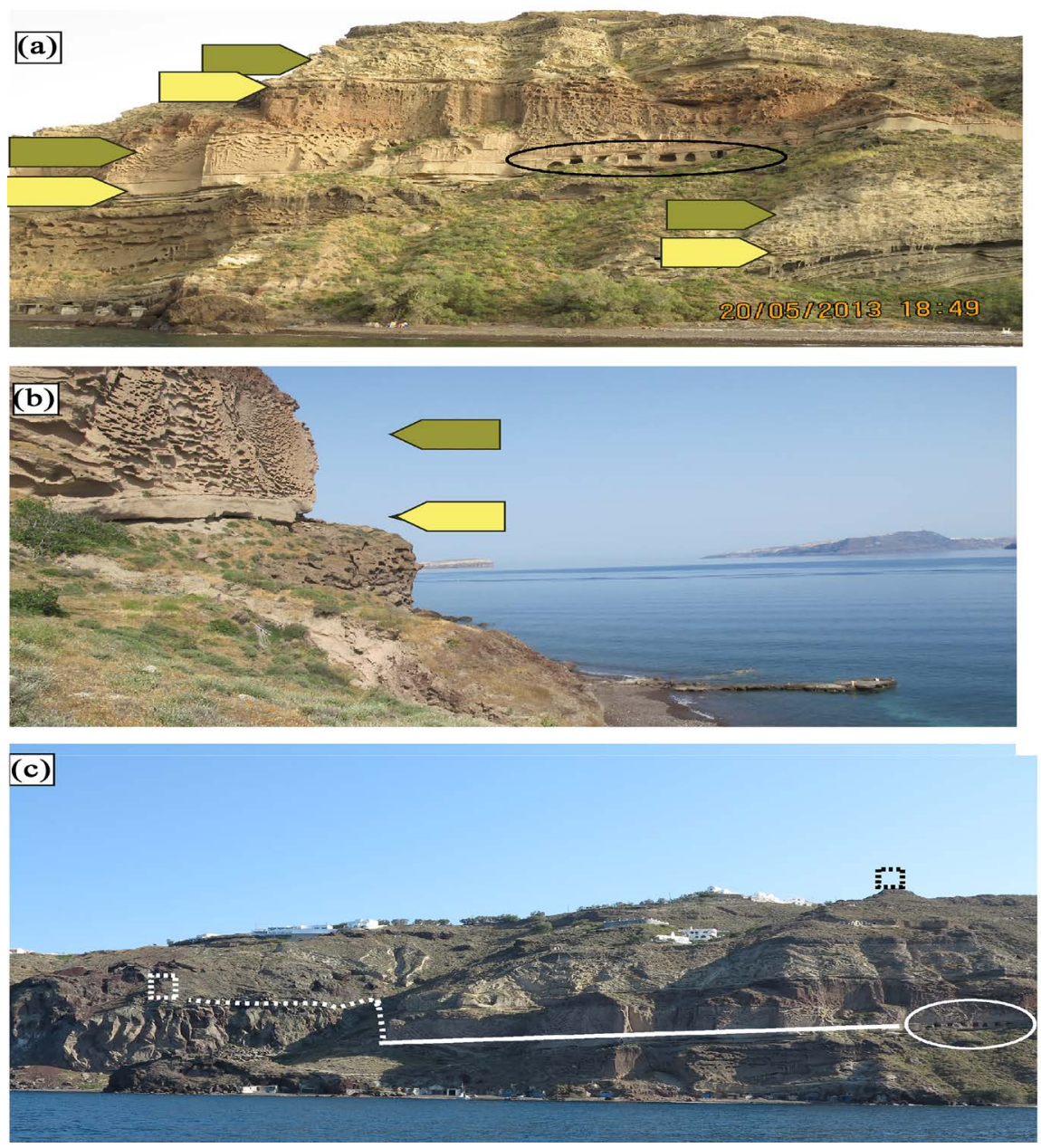

Figure 5. (a) The caldera wall at Balos harbour. Relics of the synchronous pumice mantle of the Minoan eruption are visible at three levels ( 3 arrow pairs). The three pairs mark the eruption products of the two first eruption phases (yellow arrow: air fall pumice; green arrow: base surge deposits). The evening sun highlights pumice deposits that are lying on three terraces at three levels. (b) A cross-section through pumice deposits (arrows) resting on a terrace at Balos about $40 \mathrm{~m}$ asl. It is the same terrace where 10 caves are excavated in the south and the remains of the Cycladic house are found to the north. (c) The black rectangle at the top right shows the location of the Raos excavation (residential palace excavated from 2009 to 2012 by Marisa Marthari). White rectangle: Cycladic house excavated in 1871 . The dashed line shows part of the terrace from which pumice has been removed for construction of the Suez Canal. The white line shows the remnants of the pumice mantle resting on a terrace. The ellipse shows the location of the monastery and the 10 caves dug into the Minoan pumice mantle. The pumice on the terrace here is $4.5 \mathrm{~m}$ deep. The pumice level with the 10 caves extends to the left to the old excavation site at Balos. Balos harbour is visible at the bottom left (Photos Friedrich, Katsipis).

Series" there he considered that all remnants of this house had already been removed or eroded away. He was therefore not able to appreciate that this house provided a maximum age for the pumice that buried it. Today, however, we are aware of the site where the house stood (Friedrich, 2009) and are certain that it was the Minoan eruption that buried it and not the "Lower Pumice Series". Furthermore, Cycladic objects found in the house are depicted in Fouqué's book [7] 
and are kept in the collections of the French school in Athens.

According to Simmonds et al. [32] LP2 has an absolute age of $154 \mathrm{ka}$. It is clearly impossible that pumice of this age could have buried a Bronze Age house. Even though the pumice here has been removed by quarrying it is reasonable to claim that it was pumice from the Minoan eruption that buried the house and not that from a much older eruption. Study of the geological setting around the platform on top of the lava where the house stood [33] also indicates that the pumice here had been deposited on a terrace and was not sandwiched between older and younger layers.

The terrace where the house stood can be followed for several hundred metres to the south. At some places it is still covered by the remains of Minoan pumice. A total of 10 caves have been excavated and a monastery has been built in this pumice. All the caves are only 4.50 metres deep since older deposits forming the caldera wall in the Bronze Age were encountered at this depth. This strongly supports the concept that this unit is not the product of an older pumice eruption that covered the entire island.

\subsection{Terraces and Pumice Mantle at Cape Plaka}

Every geologist working on Santorini knows the Plaka profile (Figure 6). It shows the whole sequence from the Minoan pumice on top overlying a sequence of a variety of older non-volcanic products. Pumice originally draped the profile but has largely been removed by quarrying, including the "Lower Pumice Series". In the lower part of the profile there is an unconformity where volcanic products overlie phyllites which extend down to sea level.

A few meters above the spring is a terrace where a few summerhouses are located. It continues northwards for about $200 \mathrm{~m}$. There is another terrace about halfway up the caldera wall which has been used as a donkey trail down to the harbour. These terraces were obviously covered by Minoan pumice some 150 years ago.

The unconformity on Santorini between phyllites and volcanizes that is exposed at Cape Plaka and at the nearby Cape Thermia, where the Christos church is located, might have been in use before the Minoan eruption. This can be deduced from the finding of pigments and lead minerals in the Akrotiri excavation [34] which were probably collected from this area [35]. When quarrying removed the pumice mantle the terrace became accessible again. The unconformity at Plaka is still inhabited; the Panaghia church and a summerhouse are located on this terrace. At the nearby Thermia locality the Christos church is directly built on the unconformity (Figure 7). The largest of three caves here is occupied by the church and houses have been built in the other two. The church is still in use but the two houses were abandoned a few decades ago.

\subsection{Pumice Mantle and Terraces in Old Profiles}

Scientific study of the Minoan eruption started around 1830 when the French 


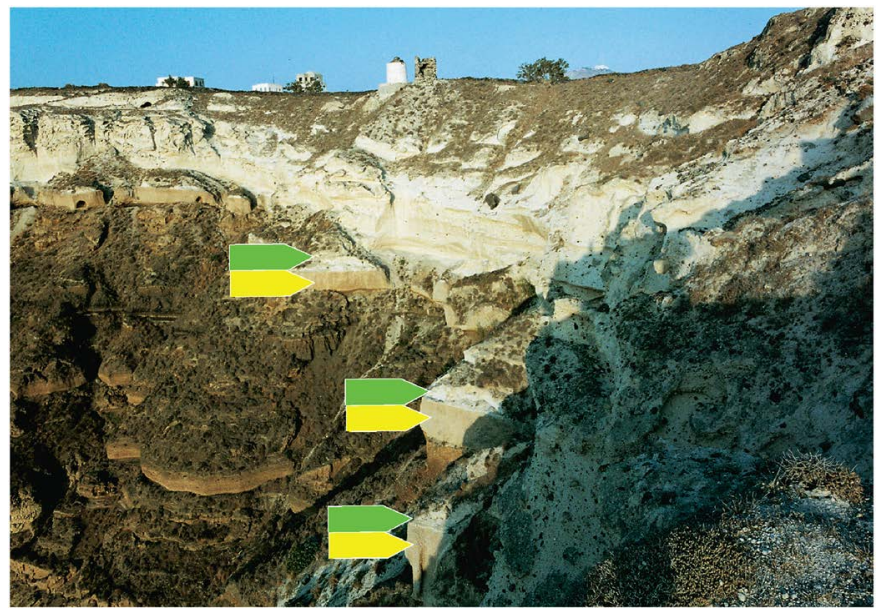

Figure 6. The upper part (ca. $60 \mathrm{~m}$ ) of the Plaka profile on the steep caldera wall. Remnants of the synchronous pumice mantle are visible at three levels (arrows) below the windmills. Only the first two eruption phases have left deposits here ( 3 arrow pairs; yellow arrow: air fall pumice; green arrow: base surge deposits) (Photo Friedrich).

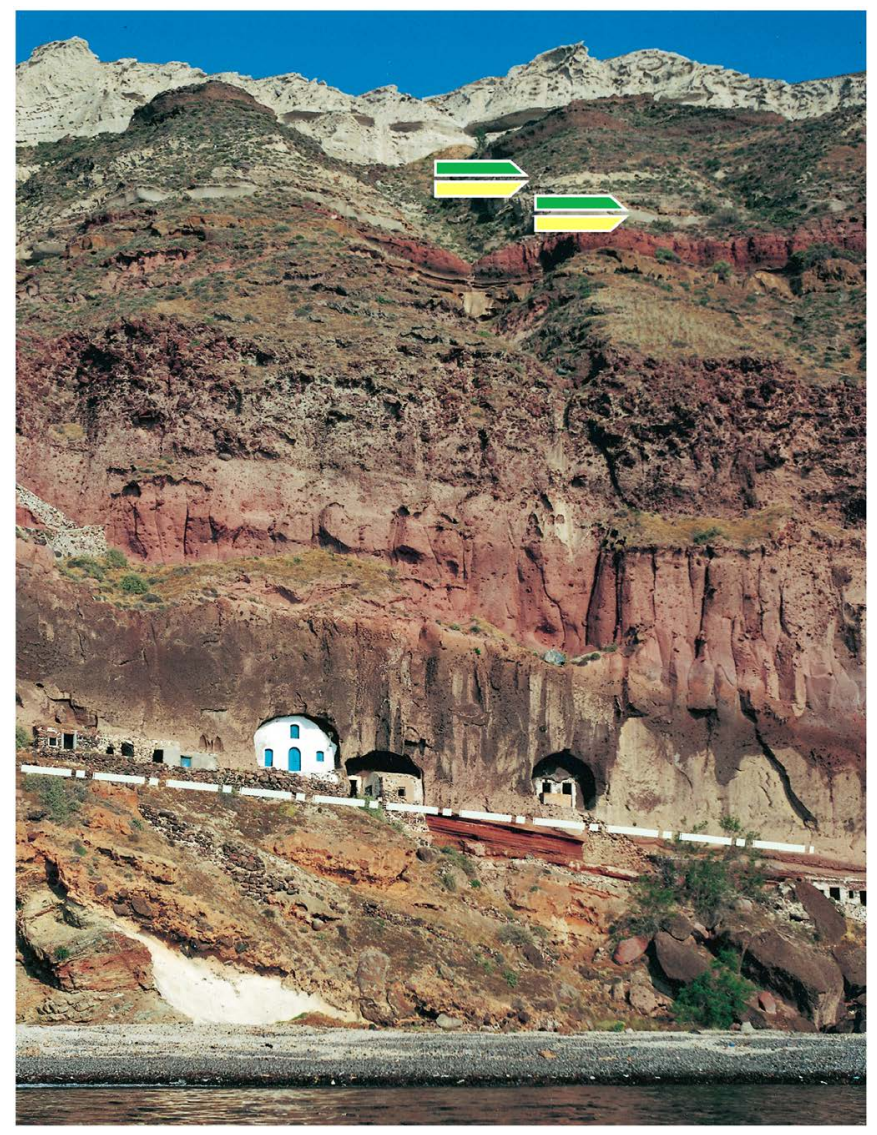

Figure 7. The caldera wall at Cape Thermia with the Christos church. The arrows mark two levels with remnants of the synchronous pumice mantle of the Minoan eruption. The level of the unconformity between phyllites and volcanites is shown by the dashed line. The Christos church and two houses are built into three caves just above the unconformity. The white patch at the bottom left is hardened pumice, probably a relic of the Minoan pumice mantle 2 arrow pairs; yellow arrow: air fall pumice; green arrow: base surge deposits) (Photo Friedrich). 
scientific Morea Expedition visited the Peloponnese, the Cyclades islands and Santorini [36]. Among the scientists on the Morea Expedition was the geologist M. Virlet. His profiles and drawings from 1834 show that the island had not yet been affected by quarrying of the Minoan pumice. A coloured profile by Virlet shows a section of the caldera wall below the town of Fira, down the zigzag road to the harbour at Katofira (Figure 8(a)). Virlet's drawing contains some important details that are of interest for present-day researchers. His number 1 layer represents a pumice layer which he recognized at several levels on the caldera wall. These pumice layers are emphasized in Figure 8(b). At least four sub-horizontal pumice-covered terraces can be recognised. The sloping units of pumice are resting on faults or joint systems. They may have provided access between the different terraces in the Bronze Age. We can identify this pumice as representing the Minoan pumice mantle. The uppermost pumice at the top of Figure 8(a) and Figure 8(b) has a variable thickness. On the left (north) it overlies the uppermost lava flow of the Skaros Lava Series, and on the right (south) it is up to twice as thick as on the left. The abandoned Fira pumice quarry is visible
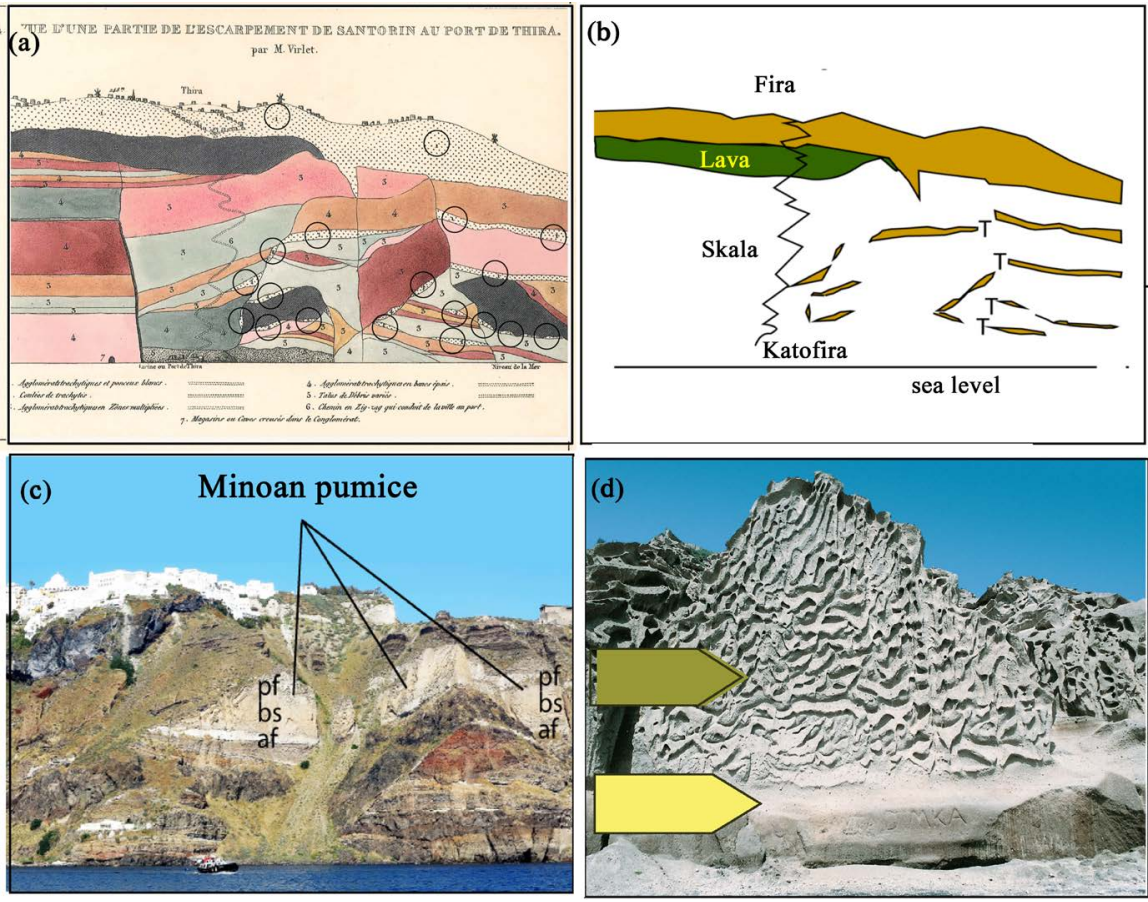

Figure 8. (a) Geological profile of the caldera wall below Fira by Virlet in 1834. White pumice outcrops marked by circles (ponceaux blanc in his legend) form the uppermost unit (which he labelled number 1). (b) Interpretation of Virlet's drawing shows that at least four terraces (T) are present below the town of Fira which most likely were accessible in the Bronze Age. (c) Photo (from 2016) of the caldera wall below Fira (top left) for comparison with the drawing by Virlet in (a). $\mathrm{af}=$ air fall; $\mathrm{bs}=$ base surge; $\mathrm{pf}=$ pyroclastic flow. (d) Weathering patterns of the first two phases of the Minoan eruption on the outer slope of the volcano south of Akrotiri. Erosion by wind and water has produced a wave-like pattern on the surface of the base surge unit (centre). Depending on the angle of sunlight the surface seems to be darker than it really is (yellow arrow: air fall pumice; green arrow: base surge deposits) (Photos Friedrich). 
at the top right centre in Figure 8(c). The pumice here is believed to originally have extended to the edge of the caldera wall, as implied by Virlet's drawing. Huge amounts of pumice have been quarried away from this locality, as can be deduced by comparing the photo with Virlet's drawing. The pumice here was up to $60 \mathrm{~m}$ thick. The whitish outcrop near the centre of the photo represents the Minoan pumice mantle in which the three classic units representing air fall, base surge and pyroclastic flow can be recognized. In Virlet's drawing this is shown as the dark grey unit in the lower centre (indistinctly labelled as number 2; "Coulees de trachytes"). He identified the white layers at the top and base as pumice but not the central base surge unit. This may well have been because of its off-white colour. The same pumice unit is shown by Virlet as thick brown and dark grey areas in the right part of his drawing.

The pumice at the top of Figure 8(a) and Figure 8(c) would be interpreted as representing the "Upper Pumice Series" and the centrally located pumice, labelled af, bs and pf, the "Lower Pumice Series" by earlier workers. We now consider that both the "Upper" and "Lower Pumice Series" belong to the Minoan eruption. In some places the so-called "Lower Pumice Series" has a slightly darker colour than the upper unit, which was one of the arguments for the two eruptions concept. However, the darker colour is caused by dark lapilli, which locally occur above the lower unit. The lapilli have been washed down by rainwater, giving rise to a dark coating on the outcrop. Furthermore, a characteristic weathering pattern of the base surge deposits commonly results in a darker impression of the surface (Figure 8(d)). Where recent erosion (or excavation) has removed the dark coating, the original whitish colour of the base surge unit is again visible.

\subsection{Pyroclastic Relicts on Analfi Island}

Anafi is a non-volcanic island situated about $30 \mathrm{~km}$ east of Santorini. Relicts of Minoan pumice were reported on Anafi [15] [37] by Keller (1981). Furthermore, Doumas \& Papazoglou [38] reported vestiges of Minoan pumice from both Anafi and Rhodes. It is important to establish the age of these deposits and whether they come from Santorini. Gertisser et al. [39] reported that pumice on Anafi could represent "Lower Pumice 2" (LP2 with a supposed age of $154 \mathrm{ka}$ ). Keller et al. [40] reported, based on chemical analyses, that the LP2 pumice is present on Anafi. However, an OSL study by Theodorakopoulou et al. [41] showed that no traces of pumice older than $21 \mathrm{k}$ years were present on Anafi. This result supports the non-existence of the "Lower Pumice Series", at least on Anafi. However, more investigations on both Santorini and Anafi are necessary to shed further light on this issue.

\section{Historic Eruptions}

The discovery of the pumice mantle on the inner side of the caldera solves some stratigraphic problems. However, it is important to realise that there were some 
more recent eruptions that could have left volcanic deposits on the inner and outer walls. Two eruptions that produced enormous amounts of pumice are particularly relevant. These are the eruptions in AD 726 on Palea Kameni and the AD 1649-1650 eruption of the Kolumbos submarine volcano, about 7 kilometres NE of Santorini. Pumice from the AD 726 eruption was reported from as far away as Abydos in the Dardanelles and on the coast of Macedonia. The oldest reports of the AD 726 eruption are given by Nicephoros (758-823): "The whole sea was filled with floating pumice". The vent of this eruption was obviously on Palea Kameni where relicts of pumice can be found in fissures. There are, however, no known traces of pumice from this historic eruption on Thera or Therasia. In this respect the $\mathrm{AD} 726$ eruption resembles that of the submarine Kolumbos volcano. A large quantity of pumice was produced by the Kolumbus eruption that filled the sea around Santorini and left traces of pumice on the coast. However, subsequent erosion by the sea, including tsunamis, has removed most of it.

\section{Conclusions}

The discovery of a synchronous pumice mantle on the caldera wall shows that the Minoan eruption deposited considerable amounts of pumice on the inner side of the Santorini caldera. However, a lengthy period of erosion and 150 years of pumice quarrying led to the loss of an enormous amount of geological and archaeological information. Our find of relicts of a synchronous pumice mantle that remained on several terraces on the caldera wall shows that it originally covered the entire caldera wall down to sea level. Field observations at Balos, Plaka, Thermia and Katofira are supported by a geological profile from 1834 that shows Santorini before it was affected by pumice quarrying. The finding of a synchronous pumice mantle from the Minoan eruption gives rise to new interpretations of the stratigraphy and geological concepts. The ages of LP1 (ca. 172,000 years) and LP2 (ca. 154,000 years) are no longer relevant because they provide ages of the sampling sites on the caldera wall upon which the pumice mantle was deposited but not of the pumice itself.

Many researchers have noted that the "Lower Pumice" is remarkably similar to the "Upper Pumice", but have nevertheless considered that they were produced by two eruptions separated by up to $172 \mathrm{k}$ years. We claim that these two pumice units are identical. Both represent products of the synchronous pumice mantle produced by the Minoan eruption. The three classic phases (Figure 1) of the Minoan eruption are visible in both the "Upper" and "Lower Pumice Series". The chemical compositions of the two pumice units are also remarkably similar [29], including the rare earth diagrams [42]. Furthermore, archaeological findings below the "Lower Pumice" at two localities (Karageorghis quarry and Balos) show that these sites were buried by the synchronous pumice mantle of the 3.6 ka Minoan eruption and not by pumice with an age of some 170,000 years. For these reasons, the two eruptions concept should be discarded. 
To summarize, our main conclusions are:

1) After the Minoan eruption, pumice mantled the entire inner side of the Santorini caldera;

2) There was only one major eruption that took place in the Bronze age (about 3.6 ka ago) and not two separated by about 150,000 years;

3) The so-called "Lower Pumice Series" does not exist on Santorini. Like the "upper Pumice Series" it is part of the Minoan eruption;

4) The inner side of the Santorini caldera had several natural terraces prior to the Minoan eruption. The pumice came to rest on these terraces. Much of it has been removed by quarrying and erosion;

5) Archaeological finds of Cycladic ruins and pottery prove that the inner side of the Santorini caldera was inhabited during the Bronze age.

\section{Acknowledgements}

We are grateful to Georgios Nomikos for help with transportation and Michael and Jeppe Friedrich for help with the fieldwork. Kirsten Molly Søholm and Kirsten Gomard helped with the manuscript and Grethe Storgaard with the illustrations.

\section{Conflicts of Interest}

The authors declare no conflicts of interest regarding the publication of this paper.

\section{References}

[1] Fouqué, F. (1869) Une Pompéi Antéhistorique. Revue des deux mondes, 83, 923-942.

[2] Friedrich, W.L. (2000) Fire in the Sea. Cambridge University Press, Cambridge, 258.

[3] Marinatos, S. (1976) Excavations at Thera VII. Bibliotheke tes en Athenais Archaiologikes Hetaireios, Athens.

[4] Palyvou, C. (2005) Akrotiri, Thera: An Architecture of Affluence 33,500 Years Old. Prehistory Monographs, INSTAP Academic Press, Athens. https://doi.org/10.2307/j.ctt3fgvrh

[5] Doumas, C. (1992) The Wall Paintings of Thera. The Thera Foundation, Athens.

[6] Friedrich, W.L. (2013) The Minoan Eruption of Santorini around 1613 BC and Its Consequences. Tagung en des Landesmuseums für Vorgeschichte Halle, 9406.

[7] Fouqué, F. (1879) Santorin et ses Éruptions. Masson \& Cie, Paris.

[8] Fouqué, F. (1998) Santorini and Its Eruptions. Translated and Annotated by A. R. McBirney. Johns Hopkins University Press, Baltimore.

[9] Neumann van Padang, M. (1936) Die Geschichte des Vulkanismus Santorins von ihren Anfängen bis zum zerstörenden Bimssteinausbruch um die Mitte des 2. Jahrtausend vor Christus. In: Reck, H., Ed., Santorin-der Werdegang eines Inselvulkans und sein Ausbruch 1925-1928, Vol. I, D. Reimer, Berlin, 1-72.

[10] Pichler, H. and Kussmaul, S. (1980) Geological Map of the Santorini Islands, (1:20 000) Appendix to: Thera and the Aegean World II. The Thera Foundation, London.

[11] Druitt, T.H., Edwards, R.M., Mellors, D.M., Pyle, D.M., Sparks, R.S.J., Lanphere, M., Davies, M. and Barriero, B. (1999) Santorini Volcano. Geological Society Memoir 19. 165. 
[12] Ninkovich, D. and Hays, J.D. (1967) Mediterranean Island Arcs and Origin of High Potash Volcanoes. Earth and Planetary Science Letters, 16, 331-345. https://doi.org/10.1016/0012-821X(72)90151-3

[13] Druitt, T.H. and Francaviglia, V. (1992) Caldera Formation on Santorini and the Physiogeography of the Islands in the Late Bronze Age. Bulletin Volcanologique, 54, 484-493. https://doi.org/10.1007/BF00301394

[14] Pichler, H. and Friedrich, W.L. (1976) Radiocarbon Dates of Santorini Volcanics. Nature, 62, 373-374. https://doi.org/10.1038/262373a0

[15] Keller, J. (1981) Quaternary Tephrochronology in the Mediterranean Region. In: Self, S. and Sparks, R.S.J., Eds., Tephra Studies NATO Advanced Study Institutes Ser. C, Vol. 75, D. Reidel Publishing Co., Dordrecht/Boston, 227-244. https://doi.org/10.1007/978-94-009-8537-7_14

[16] Sparks, R.S.J. and Wilson, C.J.N. (1990) The Minoan Deposits: A Review of Their Characteristics and Interpretation. In: Hardy, D.A., Ed., Thera and the Aegean World II, Vol. 2, The Thera Foundation, London, 89-99.

[17] Pichler, H. and Friedrich, W.L. (1980) Mechanism of the Minoan Eruption of Santorini. In: Doumas, C., Ed., Thera and the Aegean World II, The Thera Foundation, London, 15-30.

[18] McCoy, F.W. (2009) The Eruption within the Debate about the Date. Time's Up Acts of the Minoan Eruption Chronology Workshop, Sandbjerg, November 2007, 71-89.

[19] Bond, A. and Sparks, R.S.J. (1976) The Minoan Eruption of Santorini, Greece. Journal of the Geological Society of London, 132, 1-16. https://doi.org/10.1144/gsigs.132.1.0001

[20] Friedrich, W.L., Sørensen, A.H., Wilson, J.R., Fytikas, M., Pavlides, S. and Katsipis, S. (2017) A Major Change in the Stratigraphy of the Santorini Volcano in Greece. International Journal of Geosciences, 8, 767-780. https://doi.org/10.4236/ijg.2017.86043

[21] Morgan, L. (1988) The Miniature Wall Paintings of Thera. A Study in Aegean Culture and Iconography. Cambridge University Press, Cambridge.

[22] Friedrich, W.L. and Doumas, C.G. (1990) Was There Local Access to Certain Ores/Minerals for the Theran People before the Minoan Eruption? An Addendum. In: Hardy, D.A., Ed., Thera and the Aegean World III, Vol. 1, The Thera Foundation, London, 502-503.

[23] Sørensen, A.H., Friedrich, W.L. and Søholm, K.M. (2018) Metamorphoses and Hybridity in the Wall-Paintings at Akrotiri, Thera. In: Vavouranakis, G., Kopanias, K. and Kanellopoulos, C., Eds., Popular Religion and Ritual in Prehistoric and Ancient Greece and the Eastern Mediterranean, Archaeopress Archaeology, Oxford, 47-54. https://doi.org/10.2307/j.ctvndv50x.10

[24] Eriksen, U., Friedrich, W.L., Buchardt, B., Tauber, H. and Thomsen, M.S. (1990) The Stronghyle Caldera: Geological, Palaeontological and Stable Isotope Evidence from Radiocarbon Dated Stromatolites from Santorini. In: Hardy, D.A., Ed., Thera and the Aegean World, Vol. III, The Thera Foundation, London, 2, 139-150.

[25] Friedrich, W.L., Eriksen, U., Tauber, H., Heinemeier, J., Rud, N., Thomsen, M.S. and Buchardt, B. (1988) Existence of a Water-Filled Caldera Prior to the Minoan Eruption of Santorini, Greece. Naturwissenschaften, 75, 567-569. https://doi.org/10.1007/BF00377720

[26] Karátson, D., Telbisz, T., Gertisser, R., Strasser, T.I., Nomikou, P., Druitt, T., Vereba, 
V., Quidelleur, X. and Kósik, S. (2020) Constraining the Landscape of Late Bronze Age Santorini Prior to the Minoan Eruption: Insights from Volcanological, Geomorphological and Archaeological Findings. Journal of Volcanology and Geothermal Research, 401, Article ID: 106911.

https://doi.org/10.1016/j.jvolgeores.2020.106911

[27] Gorceix, H. and Mamet, C. (1871) Constructions de l'époque antéhistorique, découvertes à Santorin. Comptes Rendus, 73, 476-478.

[28] Gorée, F. (1712) A Relation of a New Island, Which Was Raised Up from the Bottom of the Sea, on the 23d of May 1707, in the Bay of Santorini, in the Archepelago. Philosophical Transactions, 27, 354-375.

[29] Günther, D. and Pichler, H. (1973) Die Obere und Untere Bimsstein-Folge auf Santorin. Neues Jahrbuch für Geologie und Paläontologie, 7, 394-415.

[30] Marthari, M. (2017) Investigating the Outskirts of the Prehistoric Town at Akrotiri, Thera. A Rich LC I/LM IA Building Complex at the Site of Raos.

[31] Tzachili, I. (2005) Excavations on Thera and Therasia in the 19th Century. A Chronicle. Journal of Mediterranean Archaeology, 18, 231-257.

https://doi.org/10.1558/jmea.2005.18.2.231

[32] Simmonds, J.M., Carey, R.J. and Cas, R. (2017) High Magma Decompression Rates at the Peak of a Violent Caldera-Forming Eruption (Lower Pumice 1 Eruption, Santorini, Greece). Bulletin of Volcanology, 79, 42. https://doi.org/10.1007/s00445-017-1120-1

[33] Friedrich, W. L. (2009) Santorini, Volcano, Natural History and Mythology. Aarhus University Press, Aarhus.

[34] Michailidou, A. (1990) The Lead Weights from Akrotiri: The Archaeological Record. In: Thera and the Aegean World III, Vol. 1, The Thera Foundation, London, 407-418.

[35] Rasmussen, S.E., Grundvig, S. and Friedrich, W.L. (2004) Composition of Pigments of Santorini Frescoes: The Rietveld Method as an Aid in Qualitative Phase Analysis. Powder Diffraction, 1145-1149. https://doi.org/10.1154/1.1643052

[36] Bory de Saint-Vincent, J.B. (1834) Expédition scientifique de Morée. Section des sciences physiques, tome II Géographie et géologie.

[37] McCoy, F.W. and Dunn, S. (2002) Modelling the Climatic Effects of the LBA Eruption of Thera: New Calculations of Tephra Volumes May Suggest a Significantly Larger Eruption than Previously Reported (Abstract). In: Proceedings of the Chapman Conference on Volcanism and the Earth's Atmosphere, American Geophysical Union, Santorini, 21-22.

[38] Doumas, C. and Papazoglou, L. (1980) Santorini Tephra from Rhodes. Nature, 287, 322-332. https://doi.org/10.1038/287322a0

[39] Gertisser, R., Preece, K. and Keller, J. (2009) The Plinian Lower Pumice 2 Eruption, Santorini, Greece: Magma Evolution and Volatile Behaviour. Journal of Volcanologicaal and Geothermal Research, 186, 387-406.

https://doi.org/10.1016/j.jvolgeores.2009.07.015

[40] Keller, J., Gertisser, R., Reusser, E. and Dietrich, V. (2014) Pumice Deposits of the Santorini Lower Pumice 2 Eruption on Anafi Island, Greece: Indications for a Plinian Event of Exceptional Magnitude. Journal of Volcanologicaal and Geothermal Research, 278, 120-128. https://doi.org/10.1016/j.jvolgeores.2014.04.009

[41] Theodorakopoulou, K., Kyriakopoulos, K., and Stamoulis, K., Rizza, M., Athanassas, C.D., Sulpizio, R. and Alcicek, M.C. (2019) Chronological Evidence for a Pre-Minoan Age of Pyroclastic Deposits on Anafi Island, Cyclades, Greece. Mediterranean 
Geoscience Reviews, 1, 17-24. https://doi.org/10.1007/s42990-019-00005-5

[42] Vitaliano, C.J., Norman, M.D., McCulloch, M.T. and Nicholls, I.A. (1990) Ash Layers of the Thera Volcanic Series: Stratigraphy, Petrology and Geochemistry. In: Hardy, D.A., Keller, Galanopoulos, V.P., Flemming N.C. and Druitt, T.H., Eds., Thera and the Aegean World III, Volume Two, Earth Sciences, The Thera Foundation, London, 53-78. 